\title{
健診における糖尿病診断に対するグリコへモグロビンと フルクトサミンの意義
}

$\begin{array}{llll}\text { 八島 } & \text { 弘昌 } & \text { 山田靖太郎 高雄 麻美 } \\ \text { 川西 昌弘 岡 本 繁 } & & \end{array}$

〈目的と方法〉蛋白質にグルコースが結合する glycationにより組織が硬化し, 血管は動脈硬化が進 行する，このような高血糖の有害性が明らかにされ， 糖尿病健診の重要性も再認識されるようになった。こ のような背景のもとに, 糖化されたへモグロビン $\left(\mathrm{HbA}_{1 \mathrm{c}}\right)$ や血清蛋白のフルクトサミン (FRA) の測定 も最近クローズアップされてきた。すでに $\mathrm{HbA}_{1 \mathrm{c}}$, FRA 共に種々の基礎的デー夕が発表され, 機器間差や 施設間差があり，測定上の問題点も指摘されている。

今般，われわれは， $\mathrm{HbA}_{1 \mathrm{c}}$ 測定に Hi-Auto $\mathrm{A}_{1 \mathrm{c}}$ HA 8121 (京都第一科学) を用い, FRA 測定は COBAS MIRA（日本ロシュ）と TBA 880 (東芝)にグリカピ 一 (中外製薬) を用い, 血糖值はダイナボットVP ス ーパーを用いるへキソキナーゼ法によって，健診者約 2,000 例の FPG, $\mathrm{HbA}_{1 \mathrm{c}}$, FRA を測定して糖尿病診断 に対する意義を検討した。

\section{〈成 績〉}

(1) 正常値の検討; 受診者 2,024 例の $\mathrm{HbA}_{1 \mathrm{c}}$, FRA の分布は正規分布を示し, $\mathrm{HbA}_{1 \mathrm{c}} 5.1 \pm 0.83 \%$, FRA $2.5 \pm 0.38 \mathrm{mmol} / l$ で, FRA については COBAS MIRA を用いる 20 施設 2,804 例の平均值 $2.59 \pm 0.38$ とよく一致した值を得た。

(2) $\mathrm{HbA}_{1 \mathrm{c}}, \mathrm{FRA}$ の群別分布; 受診者の FPG と GTTにより, 正常群 $(\mathrm{N})$, 境界群 $(\mathrm{B})$, 糖尿病群 (D) の 3 群に分類した結果, 1,189 例中正常群は 950 例 (79.9\%) で, 境界群は 188 例 (15.8\%), 糖尿病群は 51 例 (4.3\%) であった。 a) $\mathrm{HbA}_{1 \mathrm{c}}$ の群別分布; N, B, D 群各々の分布を重ね ると, D 群はほとんど正常域をハズレているが, $\mathrm{B}, \mathrm{N}$ 群は重なりが大きく,正常域へかなり入りこんでいる。

b) FRA の群別分布; $\mathrm{HbA}_{1 \mathrm{c}}$ と同様なパターンを示 すが, FRA の方が $\mathrm{HbA}_{1 \mathrm{c}}$ よりも重なりが大きく, B 群 の判別には $\mathrm{HbA}_{1 \mathrm{c}}$ の方がやや有利と思われる。

c) 群別 FRA と $\mathrm{HbA}_{1 \mathrm{c}}$ の相関; D群において FPG, $\mathrm{HbA}_{1 \mathrm{c}}, \mathrm{FRA}$ の相互の相関が最もよく, とくに $\mathrm{HbA}_{1 \mathrm{c}}$ と FRA は相関係数 0.86 であった。

(3) $\mathrm{HbA}_{1 \mathrm{c}}$ ，FRA の何れかが異常高值を示す例。 受診者 1,189 例中 FRA, $\mathrm{HbA}_{1 \mathrm{c}}$ 值の何れかが異常 高値を示すものを群別に調査したところ, 正常群では 950 例中 15 例 $(1.5 \%)$, 境界群では 188 例中 118 例 $(62.8 \%)$, 糖尿病群では 51 例中 51 例 $(100 \%)$ が高 值を示した。この内, 境界群が問題で, FRA, $\mathrm{HbA}_{1 \mathrm{c}}$ 測定を行い, GTT を省略すると約 $37 \%$ の境界型が見 逃される恐れがある。

〈結 果〉 $\mathrm{HbA}_{1 \mathrm{c}}$ と FRA の健診におけるスクリー ニングについて検討した結果, $\mathrm{HbA}_{1 \mathrm{c}}$ 測定には多少の 時間を要し, FRA は測定処理能力に優れて速く, 大量 に処理できるが, 測定值が小さく, 分布の幅が狭く, 正常と異常の区別が難しく, とくに B 群での重なりは $\mathrm{HbA}_{1 \mathrm{c}}$ よりもFRAの方がやや大きいようで, その判 定にやや困難な面がある。

$\mathrm{FRA}$ をPG と $\mathrm{HbA}_{1 \mathrm{c}}$ と組合せてスクリーニング することが, 糖尿病のより詳細なコントロールマーカ 一として有用と考える。

\footnotetext{
$\overline{\text { Hemoglobin } \mathbf{A}_{1 \mathrm{c}}}$ and Fructosamine Clinical Application for Diagnostic Usefulness of Diabetes mellitus in AMHTS

広島中央健康管理センター
} 